\title{
UPAYA MENINGKATKAN HASIL BELAJAR IPS DENGAN MENGGUNAKAN MODEL PEMBELAJARAN COURSE REVIEW HORAY
}

\author{
Oleh: Drs. Ramli, M.Pd* dan Isnawati**
}

\begin{abstract}
ABSTRAK
Pembelajaran yang terlaksana hanya satu arah sehingga peserta didik kurang aktif dan hasil belajar menjadi rendah, maka dari itu penelitian ini bertujuan untuk: (1) mendeskripsikan peningkatan aktivitas belajar peserta didik pada saat menggunakan model pembelajaran Course Review Horay, (2) mendeskripsikan peningkatan hasil belajar IPS setelah menggunakan model pembelajaran course review horay. Subjek penelitian ini adalah peserta didik kelas IV SDN 2 Ruwung Buyung Kecamatan Cempaga Hulu. Metode yang digunakan adalah Penelitian Tindakan Kelas (PTK). Hasil penelitian didapatkan bahwa: (1) terjadi peningkatan hasil belajar pada peserta didik kelas IV SDN 2 ruwang buyung kecamatan cempaga hulu setelah menggunakan model pembelajaran coursey review horay, (2) peningkatan hasil belajar peserta didik dapat dilihat dari hasil belajar pada siklus I sebanyak $46,42 \%$ peserta didik yang tuntas dan pada siklus II sebanyak $89,28 \%$ peserta didik yang tuntas.
\end{abstract}

Kata Kunci: hasil belajar dan model course review horay

\section{PENDAHULUAN}

Pendidikan merupakan kunci dalam mengembangan generasi muda. Untuk mewujudkan peserta didik yang memiliki kemampuan intelektual dan kepribadian yang baik pula harus didukung dengan pembelajaran yang baik pula.

Menurut Slameto, (2010:2) berpendapat bahwa belajar ialah suatu proses usaha yang dilakukan seseorang untuk memperoleh suatu perubahan tingkah laku yang baru secara keseluruhan, sebagai hasil pengalamannnya sendiri dalam interaksi dengan lingkungannnya. Dalam pembelajaran di sekolah terdapat mata pelajaran ilmu pengetahuan sosial (IPS). IPS merupakan salah satu mata pelajaran yang di ajarkan di sekolah, mulai dari jenjang pendidikan dasar sampai kependidikan menengah atas.

Menurut Kosasih, (dalam Trianto, 2010:173) Ilmu Pengetahuan Sosial (IPS) juga membahas antara manusia dengan lingkungannya, lingkungan masyarakat dimana anak didik tumbuh dan berkembang sebagai bagian dari masyarakat, dihadapkan pada berbagai permasalahan yang ada dan terjadi di lingkungan sekitarnya". 
IPS merupakan suatu mata pelajaran yang mengkaji kehidupan sosial yang bahannya didasar pada kajian sejarah, geografi, antropologi, dan tata negara.

Sebagai guru harus mampu merancang, memilih, menggunakan dan melakukan program pengalaman belajar dengan tepat untuk menunjang keberhasilan peserta didik dalam mendapatkan pengalaman dan kemampuan belajar untuk mencapai tujuan pembelajaran.

$\begin{array}{rrr}\text { Dengan adanya rancangan } \\ \text { pembelajaran } & \text { guru } & \text { mampu }\end{array}$
membantu meningkatkan hasil belajar IPS dengan menggunakan model pembelajaran.

Model merupakan suatu cara yang dipergunakan guru untuk mencapai tujuan yang telah ditetapkan. Menurut Mulyono, (2012:81) berpendapat bahwa "Model Pembelajaran adalah cara untuk mempermudah peserta didik mencapai kompetensi tertentu, jadi model pembelajaran dapat diartikan sebagai cara yang digunakan untuk mengimplementasikan rencana yang sudah disusun dalam kegiatan nyata agar tujuan yang telah disusun dapat tercapai secara optimal".

Sedangkan menurut Menurut Suyono dan Hariyanto, (2011:19) berpendapat bahwa "Model pembelajaran adalah seluruh perencanaan dan prosedur maupun langkah-langkah kegiatan pembelajaran termasuk pilihan cara penilaian yang akan dilaksanakan".
Dalam kegiatan belajar mengajar, model sangat diperlukan oleh guru, dengan penggunaan yang bervariasi sesuai dengan tujuan yang ingin dicapai. Seorang guru tidak akan dapat mengajar dengan baik apabila tidak menguasai model secara tepat.

Model pembelajaran Course Review horay merupakan salah satu dari sekian banyak model yang sering digunakan, karena dengan menggunakan model yang bervariasi khususnya model pembelajaran Course Review horay dalam kegiatan IPS akan memberikan sebuah nuansa baru dalam pembelajaran yang cenderung konvensional.

Berdasarkan hasil observasi kelas IV SDN 2 Ruwung Buyung kecamatan Cempaga Hulu dengan peserta didik berjumlah 28 orang, tujuan pembelajaran ilmu pengetahuan sosial (IPS) belum sepenuhnya mencapai nilai standar, hal ini bisa dilihat dari data observasi awal 54\% peserta didik kelas IV memiliki hasil belajar yang rendah dan belum mampu memenuhi nilai standar, hanya $46 \%$ peserta didik yang mencapai kriteria ketuntasan minimal (KKM).

Adapun KKM yang sudah ditentukan harus mencapai nilai 65 untuk mata pelajaran IPS. Data ini diperoleh dari wali kelas dan kepala sekolah SDN 2 Ruwung Buyung Kecamatan Cempaga Hulu, hasil belajar peserta didik banyak yang rendah ini dikarenakan dalam proses 
pembelajaran guru masih kurang kreatifitas dalam memilih model pembelajaran.

Sehingga peserta didik kurang memahami materi pembelajaran yang disampaikan oleh guru, karena guru hanya menggunakan model konvensional (ceramah) oleh sebab itu peserta didik tidak bersemangat pada saat proses pembelajaran berlangsung serta peserta didik kurang memahami materi IPS yang telah diberikan oleh guru.

Maka dari itu guru perlu menggunakan model pembelajaran yang tepat untuk meningkatkan hasil belajar IPS peserta didik kelas IV SDN 2 Ruwung Buyung Kecamatan Cempaga Hulu, salah satu adalah dengan model pembelajaran Course Review Horay.

Model pembelajaran Course Review horay merupakan model pembelajaran yang dapat menciptakan suasana kelas menjadi meriah dan menyenangkan karena setiap peserta didik yang dapat menjawab benar diwajibkan berteriak „horee!!e atau yel-yel lainnya yang disukai.

Model pembelajaran ini berusaha menguji pemahaman peserta didik dalam menjawab soal, dimana jawaban soal tersebut dituliskan pada kartu atau kotak yang telah dilengkapi nomor. Berdasarkan permasalahan yang telah dikemukakan maka penulis tertarik untuk mengadakan penelitian yang berjudul Upaya Meningkatkan Hasil
Belajar IPS Dengan Menggunakan Model Pembelajaran Course Review horay. Penelitian akan dilakakukan pada peserta didik Kelas IV SDN 2 Ruwung Buyung Kecamatan Cempaga Hulu.

Tujuan penelitian yang ingin dicapai dalam penelitian ini yaitu Untuk meningkatkan aktivitas peserta didik pada saat proses pelajaran IPS dengan menggunakan model pembelajaran Course Review horay pada peserta didik kelas IV SDN 2 Ruwung Buyung Kecamatan Cempaga Hulu dan Untuk meningkatkan hasil belajar IPS dengan menggunakan model pembelajaran Course Review horay pada peserta didik kelas IV SDN 2 Ruwung Buyung Kecamatan Cempaga Hulu.

\section{METODE PENELITIAN}

Penelitian tindakan kelas (PTK) adalah suatu pendekatan untuk memperbaiki pendidikan melalui perubahan, dengan mendorong para pendidik untuk memikirkan praktek mengajarnya sendiri, agar kritis terhadap praktek tersebut, dan agar mau untuk mengubahnya.

Menurut Kunandar (2012:46) Penelitian tindakan kelas adalah suatu penelitian yang berbasis kepada kelas. Subjek penelitiannya adalah peserta didik kelas IV SDN 2 Ruwung Buyung Kecamatan Cempaga Hulu. Teknik pengumpulan data dalam penelitian ini adalah tes 
dan observasi. Analisis data penelitian ini dimaksudkan untuk menjawab rumusan masalah. Menurut Campbell dan Fisk menyatakan bahwa "metode gabungan yaitu penggabungan antara metode kuantitatif dan kualitatif dalam suatu penelitian.

\section{HASIL DAN PEMBAHASAN}

Berdasarkan deskripsi hasil penelitian yang sudah dipaparkan sebelumnya dapat diketahui bahwa menggunakan model pembelajaran Course Review horay dapat meningkatkan aktivitas peserta didik kelas IV SDN 2 Ruwung Buyung Kecamatan Cempaga Hulu.

Keaktifan peserta didik pada pembelajaran IPS dengan menggunakan model pembelajaran Course Review horay pada siklus I mencapai 3,1 dan pada siklus II mencapai 3,7. Berdasarkan hasil pengamatan yang dilakukan oleh pengamat I dan pengamat II pada siklus I dan siklus II mengalami peningkatan. Tes hasil belajar peserta didik pada siklus I yang diperoleh dari pre-test dan post-test dengan rata-rata 45, 89 dari (4) $14,28 \%$ peserta didik yang tuntas dan (24) $85,71 \%$ peserta didik yang tidak tuntas.

Dengan memberikan materi dan menggunakan model pembelajaran Course Review horay kepada peserta didik sudah memahami materi dari sebelumnya. Maka hasil belajar peserta didik dari post-test dengan rata- rata 63,75 dari (13) $46,42 \%$ peserta didik yang tuntas dan (15) 53,57\% peserta didik yang belum tuntas. Hasil belajar siklus II yang diperoleh dari hasil post-test dengan rata-rata 74,46 dari (25) $89,28 \%$ peserta didik yang tuntas dan (3) $10,71 \%$ peserta didik yang belum tuntas. Dengan menggunakan model pembelajaran Course Review horay dapat meningkatkan hasil belajar peserta didik dilihat dari ketuntasan individu dan klasikal.

\section{KESIMPULAN}

Berdasarkan hasil penelitian yang didapat maka dapat diambil kesimpulan sebagai berikut:

1. Aktivitas peserta didik selama proses pada pembelajaran IPS lebih aktif dengan menggunakan model pembelajaran Course Review horay pada kelas IV SDN 2 Ruwung Buyung Kecamatan Cempaga Hulu menjadi lebih baik.

2. Ada peningkatan hasil belajar IPS peserta didik dengan menggunakan model pembelajaran Course Review horay di kelas IV SDN 2 Ruwung Buyung Kecamatan Cempaga Hulu Tahun Pelajaran 2014/2015. 
Bitnet Jurnal Pendidikan Teknologi Informasi, Februari 2016, Volume 1 Nomor 1, (6-10) ISSN : 2502-1923

\section{DAFTAR PUSTAKA}

Kunandar, 2012. Langkah Mudah Penelitian Tindakan Kelas Sebagai Pengembangan Profesi Guru. Jakarta: Rajawali Pers.

Mulyono, 2012. Strategi Pembelajaran. Malang: UINMaliki Press.

Slameto, 2010. Belajar dan FaktorFaktor Yang Mempengaruhinya. Jakarta: Rineka Cipta

Suyono dan M.S.Hariyanto, 2011. Belajar dan Pembelajaran. Bandung: $\quad$ PT. Remaja Rosdakarya.

Trianto, 2010. Model Pembelajaran Terpadu. Jakarta: Bumi Aksara. 